\title{
Determinants of Post-Retirement Employment in Sri Lanka
}

Perera E.A.Y.D. ${ }^{1}$ and Weerakkody W.A.S. ${ }^{2}$

Department of Human Resource Management

University of Kelaniya

yohandperera@gmail.com ${ }^{1}$ and was@kln.ac.lk ${ }^{2}$

\begin{abstract}
Sri Lanka has been undergoing the impact of population ageing. Many structural and behavioral changes begin to occur in the population as a result of this demographical shift. Reemployment after the formal retirement of employees increasingly becomes usual routinely marking it as a significant trend it in the economy. Therefore, there should be some significant determinants which determine this behavior of working after retirement in Sri Lanka. A quantitative and exploratory research study was launched as a field study depending on a comprehensive literature review. Six determinants were identified which impact to Post-Retirement Employment in Sri Lanka through the analysis. A new questionnaire was developed and then standardized after furnishing the pilot survey and reviewing by scholars, peers and other related third parties. Primary data was gathered from 97 post-retired employees. Since it was a one-time data collection, the study could be addressed as a cross-sectional study.
\end{abstract}

Keywords: Ageing, labour force, population, post-retirement employment, re-employment and retirement

Copyright: () 2018 Perera E.A.Y.D and Weerakkody W.A.S. This is an open access article distributed under the Creative Commons Attribution License, which permits unrestricted use, distribution, and reproduction in any medium, provided the original work is properly cited.

Correspondence: yohandperera@gmail.com

ORCID of authors: $\quad$ Perera E.A.Y.D. - https://orcid.org/0000-0002-8941-030X

Weerakkody W.A.S. - https://orcid.org/0000-0003-3710-8528

DOI: http://10.4038/kjm.v7i2.7576 


\section{Introduction}

Life expectancy of the communities around the world is ensured by better food, hygiene, increasing quality of health care and advances in sciences (Mayhew, 2003) and there are some notable materialized and structural changes in this increasing global population (Shultz \& Henkens, 2010). With this rapid population growth and the significant changes, people are not willing to leave the workforce (Emanuel, Simon, \& Segars, 2016). Re-employment after the retirement is a trend derived in Europe and North America at the end of the $20^{\text {th }}$ century (Arrowsmith \& McGoldrick, 1997).

The nature of retirement has changed itself considerably (Feldman \& Turnley, 1995) and also retirement is a process with multiple forms rather traditionally being concerned as a distinct and unforeseen termination of paid employment opportunity (Beehr \& Bennet, 2007 as cited by Shultz \& Henkens, 2010). As mentioned by Flynn (2010) it is exclusively obvious that some older workers who are even at the threshold of retirement are eager to obtain and exploit the advantage of policy initiatives which aim delaying the retirement. On the other hand, it is found that retired employees who re-employ themselves are noticed more happier and healthier than their non-working counterparts are (Kim \& Feldman, 2000; Zhan, Wang, Liu \& Shultz, 2009).

By the corporate sector point of view, many of primary and supportive activities in the value chain are now implemented by older workers. Even many dominant industrial countries in the world welcome retired employees into their workforces (Dumay \& Rooney, 2011). Working after the retirement is not an abnormal phenomenon to Japan and South Korea (Kuhn, 2013) because in most of Asian countries, ageing rates are rising even surpassing those of the developed countries (Lim, 2003).

Sri Lanka is going to be an aged economy by 2050 and also, a significant rate of elderly population is still economically active by fostering their family economy and the nation's economy (De Silva \& Fernando, 2013). However, there is a severe deficit of academic investigations on the extent to which the growth in employment of retired employees in the modern century (Lain \& Loretto, 2016) though there is a clear cut trend in Sri Lanka relating to the Post-Retirement Employment. Therefore this study is committed to explore the significant determinants of Post-Retirement Employment behavior in Sri Lankan labor force

\section{Review of Literature}

Depending on a comprehensive literature review for this exploratory study, it is found that there are plenty of literature available in European and American contexts but no acceptable academic investigations to be found in Asian context focusing on Sri Lanka. It is discovered couple of socio economic theories and factors affecting to the post-retirement employment decisions of an employee focusing on Sri Lanka.

\section{Theoretical Background}

Strong theoretical support is obtained by the Work-Adjustment Theory (Dawis, England \& Lofquist, 1964). If there is a best fit between rewards and personal values, an employee may remain at the workplace even without considering the retirement regulations. To fulfill this situation, there is another best-fit to be met from the organizational aspect which is called the fit between employee's abilities and job demands. If both fits are fulfilled, employees adjust themselves with the workplace. Employer could expect an organizational citizenship behaviour from the employee 
because values and job related skills orient with the current job and the organization.

Activity Theory (Havighurst, 1961) institutes a strong foundation to the purpose of this study. It is explained if elders who could be active and healthier, personal relationships are more satisfied in later life. This theory influences indirectly to the concept of Post-Retirement Employment. The theory suggests that older people should continue the previous life roles, relationships and activities (working, caring and volunteering) while addressing new life roles (Zacher \& Rudolph, 2017). Thus, it is not expected a relaxing or isolated life from older people but to be busier as before the retirement. But it is also disclosed that this theory ignores the socio-economic and health inequalities of older workers.

Post-Retirement Employment is associated with the Continuity Theory (Atchley, 1971). Under this theory, it is ascertained that most of older workers maintain activities and relationships from previous life stages. Thus, they could maintain their occupational related relationship and activities (job) even after the retirement. This was presented as an extension of the activity theory and there are two types of continuities coming under under this theory. Internal continuity demarcates the memory on ideas, experiences, affect and skills whereas external equity emphasizes the role performance, activities and relationships. Having focused on Post-Retirement Employment, it is justified the preference of older people toward re-employment and the consistency of their work related features such as personality, values, preferences and beliefs.

Job Search Theory (McCall \& Mortensen, 1970) makes a significant contribution to foster this study domain of PostRetirement Employment. The emphasis of this theory is, age is not a concerning fac- tor for finding the most suitable job opportunity even in later ages (after the retirement). Thus, age becomes an immaterial factor in job-search model and one of its basic assumption is that individuals have infinite lifetime (Faggian, 2014).

\section{Factor Exploration}

Depending on the previous literature on this study domain, fourteen factors were explored affecting to the Post-Retirement Employment.

Expertise: Skills of older workers is a key factor for productivity which correlates with job performance (Turek \& PerekBialas, 2013). The skills required from employees in the modern century differ from older skill sets and employees should be up to date and maintain their modern level skills (Robinson, 2000; Shaw, 2001 as cited in Patrickson \& Ranzijn, 2003).

Motivation for Post-Retirement Employment: Vroom (1964) defined motivation as a process governing the choice made by an individual among alternative forms of voluntary activity. Future time perspective and goal orientation define the relationship between ageing and motivation to stay employable (Elliot \& McGregor, 2001; Carstensen, 2006 as cited in Emanuel, Simon \& Segars, 2016).

Post-Retirement Learning: Post-retirement learning highly correlates to the experience that gained at the workplaces by retired employees (Paul, Kate, \& Black, 2015). Both older male and female employees now want not only to retain in their jobs but also retrained for sharpening the future (Walker, 1990). There is an inverse relationship between receiving developmental opportunities and at the job and intention of full retirement which means future development potential for older workers if they continue working without retiring (Zappala, Depolo, Fraccaroli, Guglielmi, \& Sarchielli, 
2008). Schlosser, Zinni and ArmstrongStassen (2012) acsertained that there is a persuasion among retirees to arrive back to the labour market with the intention of upgrading the knowledge, skills and abilities and those retirees could be called as continuos learners.

Self-Actualization: Many managerial employees in the corporate world modernly perceive that older labour could be applied as a substitute to the younger labour (Arrowsmith \& McGoldrick, 1997). Many retired employees are nowadays looking for re-employing themselves to exploit sufficient level of opportunities to deliver their tacit knowledge onto younger generations (Flynn, 2010). Meaningfulness of working becomes a prerequisite for retired employees because self-identity and the work role could leave a person to seek an employment at retirement ages (Fasbender, Wang, Voltmer, \& Deller, 2015). Occupational Generativity enables post-retired employees unleash their potential and work in mentoring capacities for younger employees at workplaces.

Health Conditions: This is a widely discussed matter in terms of reemployment of older workers. Real health status could make an impact to determine retirement age (Messe, 2012). Ill-health is one of the main cause which impacts on the retirement at the mandatory retirement age (Vodopivec \& Arunatilake, 2008). Person's ability to carry out the work such as physical limitations, health problems of the worker and health of the worker's partner (spouse) are significantly impact to retirement decisions made by older workers (Shacklock \& Brunetto, 2011).

Occupational Demands: Workplaces should be recreated that making sensitive to the needs and preferences of older employees (Koc-Menard, 2009). It is concluded the necessity of proper ergonomics for older workforce is critical (Roper \& Yeh, 2007). Pundt, Wohrmann, Deller and Shultz (2015) pointed out the corresponding occupational characteristics associating to occupational demands namely occupational appreciation, occupational autonomy and occupational contact which are relevant in the context for post-retirement work. It is vital to re-arrange workplaces "retiree friendly" (Dessler \& Varkkey, 2009).

Legal Enforcements: Legal enforcements play an essential role for enabling re-employability of post-retired employees but rigourous legal status could lead for a deterioration the reremployability (Conen, Dalen, \& Henkens, 2012). Labour legislature in Sri Lanka should be flexibly amended to enable older workers to work after the retirement for flex working in order to increase labour force participation in Sri Lanka (Vodopivec \& Arunatilake, 2008). In Sri Lanka, retirement age for public sector employees is 60 (compulsary retirement) whereas 55 is the retirement age for private sector employees (for female employees, retirement age is 50). However, there are cosiderable excemptions for this retirement age margins.

Financial Sustainability: Finance is the most prioritized reason which pushes older employees for post-retirement employment (Schlosser, Zinni, \& Armstrong-Stassen, 2012). Older workers continue to work because of financial reasons (Kooij, Lange, Jansen, \& Dikkers, 2008). Retirees may need to maintain an affordable luxury living with accomplishing comparatively higher living standards in the life (Schlosser, Zinni, \& Armstrong-Stassen, 2012). Monthly income is regularly secured for post-retired employees because there is no significant evidence to prove the decline of monthly earning of older employees (Charni \& 
Bazen, 2017). Younger employees are lower paid but older employees are highly paid (Hallberg \& Eklof, 2010).

Intentions of the Employer: Depending on the organizational support theory, perceived organizational support could get re-energized older workers to continue their careers even after the formal retirement (Cheung \& Wu, 2013). Corporate restructuring may impact either positively or negatively to older workers. But older workers greatly demand to re-employ themselves in small and medium scale enterprises (SME) than giant organizations (Arrowsmith \& McGoldrick, 1997). Employers are willing to offer more benefits to older workers in order to retain and keep satisfied them (Buyens, Dijk, Dewilde, \& De Vos, 2009). But there are some discriminatory practices adapted by employers in terms of selection, performance appraisal, career advancement, interpersonal interactions and training and development (Cadiz, Pytlovany, \& Truxillo, 2017).

Retirement Benefits: Accessing for social security schemes is a fundamental right (Bekemans, 2007). Elderly population could make a great impact on rising social insurance and pension schemes (Aaltio, Salminen, \& Koponen, 2014). Some employees may retire earlier even before the formal retirement age due to the entitlement for receiving higher amounts of retirement benefits (Hallberg \& Eklof, 2010). In Sri Lanka, there are six legalized and approved retirement benefit schemes namely, Public Service Pension Scheme (PSPS), Employee Provident Fund (EPF), Employee Trust Fund (ETF), Farmers' Pension and Social Security, Fishermen's Pension and Social Security Benefit Scheme (FSHPS) and Self - Employed Persons Pension Scheme (SPPS).

Declining Fertility Rates: Sri Lanka is experiencing in declining fertility rates which seriously cause to population ageing in the country (Abeykoon, 1996; De Silva, 1994; Siddisena, 2004; De Silva \& Fernando, 2013). Europe is experiencing the lowest fertility rate in the history by recording 1.58 children per couple (Buyens, Dijk, Dewilde, \& De Vos, 2009). Declining fertility rates is perceived as a prolonged factor which leads for post - retirement employment because European Union and some other individual European countries decided to increase the birth rate within those countries decided to increase the birth rate as a long term initiative for the labour market unbalance (RAND, 2005 as cited Buyens, Dijk, Dewilde and De Vos, 2009).

Increased Life Expectancy: Sri Lanka is experiencing the increase of life expenctancy by decreasing the Crude Mortality Rate correspondingly the decline of fertility rates. From 1946 to 1998 expectation of life - span at birth of Sri Lankan males has risen from 43.3 years to 71.2. For female Sri Lankans, it has increased from 41.6 years to 75.8 years during the same period. Crude birth rate in Sri Lanka was 16.9 (live births to 1000 people) in 2014. But it was 18.8 in 2008. Parallely, crude death rate was 6.2 deaths to 1000 poplation in Sri Lanka in 2014 but it was just 5.9 in 2008 .

Job Security: It was depicted that job security of older workers depends on the clasg of expectations between older employee and the employer (Patrickson \& Ranzijn, 2003). There are several rifidities in the job market which disable retired employees to reemploy themselves and making vulnerable their future job security (Hurd, 1993). Job security is a matter which largely depends on the excellent perofrmance that employee could show (Cadiz, Pytlovany, \& Truxillo, 2017). But job performance is not necessarily reduce with age (Brough, Johnson, Drummond, Pennisi, \& Timms, 2011). With the interlink to the Spot 
Market Theory, fiems pay to its workers in a perfectly competitive labour market to their marginal product without concerning the age (Conen, Dalen, \& Henkens, 2012).

Family Accomplishments: Elderly population may move to another job even after the retirement because the family headdhips they bear. It is a cultural value that being elderly with their children and grand children (De Silva \& Fernando, 2013). Extensively, elderly males provide material support to their children whereas elderly support them in tangible aspects (Perera, 1999). Older people need to make some changes in their living environments for either adapting to the current recidencies or relocating to cope with a more supportive environment due to decline their capacities (World Health Organization, 2015).

\section{Theoritical Framework}

Fourteen factors are identified which impact to post - retirement employment decisions of retired employees in Sri Lanka depending on the literature that available in both local and global contexts. Those are comprised into a diagram as per figure 01 .

\section{Methods}

Quantitative approach was selected as the approach of the current study and it is deemed as an exploratory research work since the involvement in a factor exploration. Exploratory study should be undertaken when not much information or awareness about the research purpose (Sekaran, 2010). Severe inadequacy of extended literature in the recent academia creates the research gap and it leads this attempt to further carry out as an exploratory study. The research problem is "what are the significant determinants of postretirement employment in Sri Lanka?" Unit of analysis is the individual (a post retired employee) and launched as a field study. This is considered as a cross sectional study because it entails one - shot data collection.

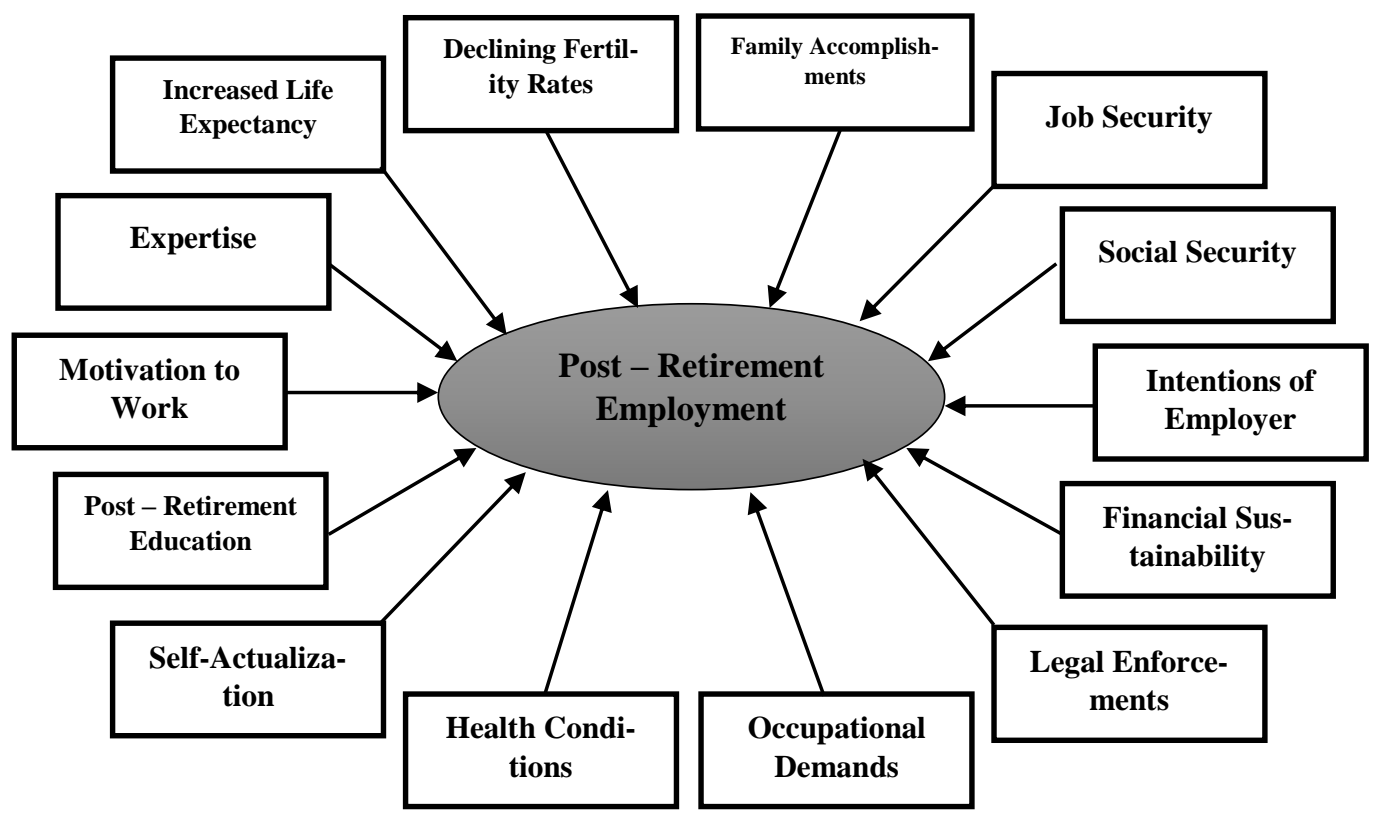

Figure 01: Determinants of Post-Retirement Employment in Sri Lanka (Literature Based) Source: Author

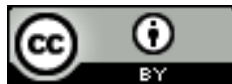


Since this is a quantitative study, monomethod was applied (Saunders, Lewis, \& Thornhill, 2009) because only single quantitative data collection technique was adopted. That is questionnaire method. No standard questionnaires were available to the current study so that self - administered questionnaire was taken for the data collection after ensuring reliability and validity. There is a high scholarly involvement (research supervisor, research coordinator and other academicians) in building up the questionnaire and amended it to theorize for this study purpose.

\section{Sample}

Population of the current study is unknown. Because no acceptable statistics available to ascertain the data of the population which is entire post - retirement community in Sri Lanka. Therefore convenience sampling method was applied as a non - probabilistic sampling technique. The sample demarcated only to 97 respondents with ensuring $69.3 \%$ response rate. There were no standard measurements for this domain of study in the literature therefore had to come up with a self-made questionnaire. Pilot survey was launched and Reliability and validity were ensured. Cronbach's Alpha value was 0.745 which ensures the reliability and KMO measure of sample adequacy was 0.569 which ensures the validity. The sample size for the pilot survey is 25 and the current study is carried out further since reliability and the validity of the sample was clearly ensured at the pilot survey.

\section{Findings and Discussion}

It is ascertained that average retirement age in Sri Lanka gender wise is 62 years for male employees and 61 for female employees. Public sector confirms the highest employable age that is 63 years. It is 62 years in the private sector and 61 years is the average retirement age in both non - government and semi - government sectors. Sample depicts the male dominancy in post - retirement employment because female representation of the sample only demarcates to $33 \%$ (only male and female are default genders).

$81.4 \%$ of post - retired employees are married and $12.4 \%$ are widowed. $51.5 \%$ of the respondents are currently living in urban areas in Sri Lanka and $41.2 \%$ located their residencies in semi - urban areas in the country. Only $7.2 \%$ are living in rural areas. 65\% of the sample represent Colombo and Gampaha districts. 78.4\% are heads of families and not in the depending capacity. Therefore majority of post - retired employees still belong family commitments. $34 \%$ of the families have 4 members including the head where post - retired employees bear the headship. There are only 3 members in $32 \%$ families in the sample.

$66 \%$ of post - retired employees are currently employed in the private sector and $21.6 \%$ in the public sector. Non - government sector records the lowest post - retirement employability in Sri Lanka demarcating to $4.1 \% .56 .7 \%$ of post - retired employees do not continue their careers with the same employer that they were employing before the retirement. $40.2 \%$ which is the majority enables within their jobs as permanent employees and $35.1 \%$ are employed on contract employees. $18.6 \%$ are temporary employees.

$74.2 \%$ of post - retired employees are full - time workers treating as the main commitment in their post - retired life. $11.3 \%$ employees are part time workers and $7.2 \%$ are flex workers. Work capacity wise, $37.1 \%$ are currently employing in managerial positions in every sector. Same percentage is employed in operational level and $16.5 \%$ employed as executives. Only 9.3\% are working in technical side jobs. 
Perera E.A.Y.D., Weerakkody W.A.S., KJM, 2018, 7 (2)

Table 3: Reliability of the Sample of the Study

\begin{tabular}{|l|l|l|}
\hline $\begin{array}{l}\text { Cronbach's Al- } \\
\text { pha }\end{array}$ & $\begin{array}{l}\text { Cronbach's Alpha Based on Stand- } \\
\text { ardized Items }\end{array}$ & $\begin{array}{l}\text { N of } \\
\text { Items }\end{array}$ \\
\hline 0.853 & 0.856 & 0.856 \\
\hline
\end{tabular}

Source: Survey Data (2017)

Table 2: Reliability of Each Statistically Measurable Determinant

\begin{tabular}{|l|l|r|}
\hline No & Factor & \multicolumn{1}{|c|}{ Cronbach's } \\
& & 0.787 \\
\hline 1 & Expertise & 0.748 \\
\hline 2 & Motivation for Post - Retirement Employment & 0.616 \\
\hline 3 & Post - Retirement Education & 0.641 \\
\hline 4 & Self - Actualization & 0.595 \\
\hline 5 & Health Conditions & 0.765 \\
\hline 6 & Occupational Demands & 0.766 \\
\hline 7 & Financial Stability & 0.627 \\
\hline 8 & Employer Intentions & 0.491 \\
\hline 9 & Job Security & \\
\hline
\end{tabular}

Source: Survey Data (2017)

Table 1: Validity of the Sample of the Study

\begin{tabular}{|l|l|r|}
\hline \multicolumn{2}{|l|}{ Kaiser-Meyer-Olkin Measure of Sampling Adequacy. } & 0.768 \\
\hline Bartlett's Test of Sphericity & Approx. Chi-Square & 307.690 \\
\cline { 2 - 3 } & df & 36 \\
\cline { 2 - 3 } & Sig. & 0.000 \\
\hline
\end{tabular}

Source: Survey Data (2017)

Kelaniya Journal of Management | 2018 | Vol. 07 | Issue 02 | Page 45 
$51.5 \%$ of post - retired employees retired at the age of 55 years. $21.6 \%$ retired at completion of 60 years. $2.1 \%$ retired at the age of 65 years. $92.8 \%$ of post - retired employees were eligible for any kind of retirement benefit in Sri Lanka. Majority was beneficiaries of Public Service Pension Scheme (PSPS) and that was 59\%. $38 \%$ were eligible for Employee Provident Fund (EPF) and Employee Trust Fund (ETF).

\section{Findings from Exploratory Factor Analysis}

Reliability was ensured of the data collected. As the depiction table 01, the Cronbach's Alpha value was 0.853. As mentioned by Nulty (2010) this study could be treated as reliable because the alpha value exceeds 0.70 . Moreover, the same author attest that taking alpha value at least 0.50 , it is sufficient amount for the further implementation of an exploratory study.

It is noted that only $\mathbf{9}$ determinants are statistically measurable which applied the Exploratory Factor Analysis (EFA). Another 3 factors are measurable but unable to apply the Exploratory Factor Analysis. Cronbach's Alpha values of each statistically measurable determinant are presented by table 02. Mean values were taken for the analysis of each determinant. Here, the reliability of $9^{\text {th }}$ factor (Job Security) is not ensured because it is below 0.50 . Construct validity was ensured KMO measure of sample adequacy which was 0.751 as depicting under table 03 . $69.9 \%$ of the total variance was explained by first three components. It is presented under table 04. Even though 9 statistically measurable determinants finalized, the component matrix classified all the determinants only under component 01 and component 03 . Under the component 02 ,

Table 4: Total Variance Explained

\begin{tabular}{|l|r|r|r|r|r|r|}
\hline \multirow{2}{*}{ Component } & \multicolumn{3}{|c|}{ Initial Eigenvalues } & \multicolumn{2}{|c|}{ Extraction Sums of Squared Loadings } \\
\cline { 2 - 7 } & Total & $\begin{array}{c}\text { \% of } \\
\text { Variance }\end{array}$ & $\begin{array}{c}\text { Cumulative } \\
\%\end{array}$ & Total & $\begin{array}{c}\text { \% of Vari- } \\
\text { ance }\end{array}$ & $\begin{array}{c}\text { Cumulative } \\
\%\end{array}$ \\
\hline 1 & 3.704 & 41.150 & 41.150 & 3.704 & 41.150 & 41.150 \\
\hline 2 & 1.415 & 15.721 & 56.871 & 1.415 & 15.721 & 56.871 \\
\hline 3 & 1.174 & 13.045 & 69.916 & 1.174 & 13.045 & 69.916 \\
\hline 4 & .746 & 8.285 & 78.201 & & & \\
\hline 5 & .601 & 6.675 & 84.876 & & & \\
\hline 6 & .411 & 4.565 & 89.441 & & & \\
\hline 7 & .346 & 3.845 & 93.287 & & & \\
\hline 8 & .328 & 3.648 & 96.935 & & & \\
\hline 9 & 3.065 & 100.000 & & & \\
\hline
\end{tabular}

Source: Survey Data (2017) 
no any factor was loaded. The component matrix is presented under table 05 .

Finalizing the Determinants of Post Retirement Employment in Sri Lanka

Component 01 was renamed as Late Career Meaningfulness. There are three types of meaning of working called social meaning, personal meaning and financial meaning of work (Fasbender, Wang, Voltmer, \& Deller, 2015). All the factors loaded under component 01 are covered by those three meanings of work. Therefore, the author of the current study exclusively applied the name, Late Career Meaningfulness for this component.
Component 03 was renamed as Health Conditions. Plenty of academic reviews available explaining the impact of health conditions on late career employment decisions around the world. But here it is demarcated only to the annual report of World Health Organization (2015) which demonstrates comprehensively the health status of older workers.

There are another three factors called Legal Enforcements, Family Accomplishments and Social Security. For this determinants it was impossible to apply Exploratory Factor Analysis to quantify statistically but results were obtained by the univariate analysis. Therefore those are not rejected.

Table 5: Component Matrix with Factor Loading Values

\begin{tabular}{|l|c|c|c|}
\hline & \multicolumn{3}{|c|}{ Component } \\
\cline { 2 - 4 } & 1 & 2 & 3 \\
\hline Mean for Factor 01 - Expertise & $\mathbf{0 . 7 0 9}$ & -0.343 & 0.028 \\
\hline $\begin{array}{l}\text { Mean for Factor 02 - Motivation for Post - Retirement } \\
\text { Employment }\end{array}$ & $\mathbf{0 . 6 9 8}$ & -0.450 & -0.272 \\
\hline Mean for Factor 03 - Post - Retirement Education & $\mathbf{0 . 5 7 4}$ & -0.443 & -0.405 \\
\hline Mean for Factor 04 - Self - Actualization & $\mathbf{0 . 7 1 7}$ & -0.263 & 0.418 \\
\hline Mean for Factor 05 - Health Conditions & 0.396 & 0.285 & $\mathbf{0 . 6 0 6}$ \\
\hline Mean for Factor 06 - Occupational Demands & $\mathbf{0 . 6 6 8}$ & -0.111 & 0.433 \\
\hline Mean for Factor 08 - Financial Sustainability & $\mathbf{0 . 6 5 4}$ & 0.546 & -0.192 \\
\hline Mean for Factor 09 - Intentions of the Employer & $\mathbf{0 . 6 6 4}$ & 0.516 & -0.067 \\
\hline Mean for Factor 13 - Job Security & $\mathbf{0 . 6 3 2}$ & 0.414 & -0.405 \\
\hline a. 3 components extracted. & & & \\
\hline
\end{tabular}

Source: Survey Data (2017) 
Finally, in the list of determinants, Declining Fertility Rates and Increased Life Expectancy were leading determinants of post - retirement employment which impact over decades. Since these are socioeconomic factors, it was impossible to measure and also data was not collected because it is out of the scope of the current study. But since there is a strong literature support to justify both determinants, those are not rejected. Then, the determinants of post - retirement employment in Sri Lanka are Late Career Meaningfulness, Health Conditions, Legal Enforcements, Family Accomplishments, Social Security and Declining Fertility Rates and Increased Life Expectancy.

\section{Comments by Respondents}

In addition to the factors explored from the literature, some respondents in the sample pointed out factors which affect their post - retirement employment decisions. Some of key comments by respondents are as follows.

- Need for gaining a distinct experience in a different field.

- Uniqueness of the talent.

- Integrity and commitment to work.

- Non - availability of a second layer of the organizational hierarchy.

- Passionate to work (teaching and lecturing).

- Serve to the motherland.

It is tracked that not only person related reasons impact to post - retirement employment decisions but also organizational related reasons which complied much the key findings of this study.

\section{Limitations}

Definitional ambiguity makes an impossibility to be provided an independent definition to the term of retirement because it depends both length of the service period and completion the contract period of service. Consideration only post - retired employees, working for a salary is another limitation of this study because not all post - retired employees are employed under an employer for a salary. There are some retired workers who reactive as voluntary working, investors, entrepreneurs and self-employees. But this study only addresses the post - retired employees which creates a demarcation.

The sample for the selected study purpose limits only to 97 individuals. But for reaching to a highly reliable result, it is important to move for bigger sample than this. Non-Availability of standard measurements in the relating and existing literature becomes a significant issue since this is the very first attempt in Sri Lanka to explore the factors affecting to post retirement employment. Therefore it was made a new questionnaire with conducting the pilot survey.

\section{Conclusions and Recommendations}

Male employees hold the highest potentiality for post - retirement employment opportunities and the private sector in Sri Lanka is the most hospitable place for the post - retirement employment for both male and female employees. Furthermore, it is determined that bearing family headships, being married and living in urban or semi-urban area significantly impact to post - retirement employment in Sri Lanka by guaranteeing the determinant of Family Accomplishment. Moreover, retired workers are not financially satisfied therefore, they shift to re-employ themselves after formal retirement though they are entitled for retirement benefits. The employment opportunities of post - retired workers are assured by the employment agreement because majority are permanent and contract basis employees.

Readjustment of retirement age limits is recommended to amend the retirement 
age limits as 62 years for male employees and 61 years for female employees in the long run. Because the results of the study demonstrate that working community is reluctant to retire soon after completing the retirement age. Those are the average retirement ages of both female and male employees as per the analysis of the study.

Post - retirement educational opportunities become vastly available so that training and coaching are essential for post - retired employees since majority of such workers shift to another organization to embark their second career after getting retired.

Government cost restructuring is another potential and benefit claiming age limits are recommended to be extended for EPF and ETF beneficiaries. Since the late life income is secured for post - retired employees, Monthly contribution for such retirement benefit schemes could also be recommended to reduce. Strategic manpower planning is vital since post - retirement employment is a rapid growing trend in Sri Lanka, organizations should prepare to welcome them in the near future. Organizations in the industry highlighting the corporate arena will not suffer labour deficits anymore in the future if they are ready to welcome retired employees who are looking for the second career initiation to fill up future vacancies. Therefore it is suggested to the institutional sector to come up with non - discriminatory hiring practices and fair treatments to everyone in every industry.

Institutional and national level occupational appreciation would be a responsibility of both the corporate and the government sector to recognize the contribution to the national income expansion by post - retired employees as senior citizens in the country. Therefore appreciating 'senior employee' could be applied as a non-financial motivation practice. This practices is not strange to Sri Lanka be- cause handful of organizations have already adapted this practice but here it is convinced that this practice should be widely accepted by both the private and public sectors. Finally, restructuring reward systems in private sector institutions is intentionally emerging because it is critically commended to introduce 'Age-Based' compensation system instead of 'performance-based' compensation systems. Because in the coming future, a significant portion of the workforce will be represented by the 'first time retired employees' so that age-based compensation system could lead to create a 'retiree-friendly atmosphere' within organizations.

Developing an initial questionnaire including quantifiable scales to measure the qualitative concept, post-retirement employment is recognized as one of significant contribution from this study to the existing academia. But still this questionnaire is not a standardized measurement so that it is critically needed the studies in future attempting to standardize the measurement scales.

\section{Future Research Potentials}

Since this is the first exploratory study carried out in Sri Lankan context in digging out the factors affected to post-retirement employment in Sri Lanka, it is further suggested to find out the following research gaps through launching scientific studies depending on the insights produced by the current study.

- How discrimination practices impact on the post - retirement employment in Sri Lanka? (Determinant of intentions of the employer is not covered by this study).

- Impact of Crude Birth Rate (CBR) and Crude Death Rate (CDR) on Post - Retirement Employment in Sri Lanka. (Fully neglected from the analysis in this study). 
- More researching on the impact of Sri Lankan labour legislature on Post Retirement Employment in Sri Lanka. (Legal enforcements)

- Relationship between earnings and Post - Retirement Employment.

\section{References}

- Aaltio, I., Salminen, H. M., \& Koponen, S. (2014). employees and human resource management evidence of gender-sensitivity? Equality, Diversity and Inclusion: An International Journal, 33(2), 160176. doi:https://doi.org/10.1108/EDI10-2011-0076

- $\quad$ Arrowsmith, J., \& McGoldrick, A. E. (1997). A flexible future for older workers? Personnel Review, 26(4), 258-273.

doi:https://doi.org/10.1108/0048348 9710172060

- $\quad$ Beck, V., \& Quinn, M. (2012). Older and younger workers: the equalling effects of health. Education + Training, 54(7), 592-696. doi:10.1108/00400911211265639

- Bekemans, L. (2007). SOCIAL SECURITY AND EMPLOYMENT: AN INSTRUMENTAL LINK. International Journal of Sociology and Social Policy, 19-28.

- $\quad$ Buyens, D., Dijk, H. V., Dewilde, T., \& De Vos, A. (2009). The aging workforce: perception of career ending. Journal of Managerial Psychology, 24(2), 102-117. Retrieved July 06, 2017

- Cadiz, D. M., Pytlovany, A. C., \& Truxillo, D. M. (2017, March). Ageism in the Workplace. Oxford Research Encyclopedia of Psychology, 1-24. doi:10.1093/acrefore/978019023655 7.013 .2
- Central Bank of Sri Lanka. (1998). EMPLOYEES' PROVIDENT FUND ACT (Incorporating Amendments up to 31st December, 1998 ). Colombo: Department of Government Printing, Sri Lanka.

- Central Bank of Sri Lanka. (2015). ECONOMIC AND SOCIAL STATISTICS OF SRI LANKA 2015 (Vol. 37). Rajagiriya, Western, Sri Lanka: Central Bank Printing Press.

- Central Bank of Sri Lanka. (2016). Annual Report - 2016. Colombo: Central Bank of Sri Lanka.

- Charni, K., \& Bazen, S. (2017). 2017. International Journal of Manpower, 38(1), 4-24.

- Cheung, F., \& Wu, A. M. (2013). Older workers' successful aging and intention to stay. Journal of Managerial Psychology, 28(6), 645660.

- Conen, W. S., Dalen, H. P., \& Henkens, K. (2012). Ageing and employers' perceptions of labour costs and productivity. International Journal of Manpower, 629-647.

- De Silva, I. W., \& Fernando, D. P. (2013, July). Changing Causes and Consequences of Labour Force Participation Trends among the Elderly in Sri Lanka. Sri Lanka Journal of Advanced Social Studies, $3(2)$.

- Department of Census and Statistics. (2016). Sri Lanka Labour Force Survey Annual Report - 2016. Ministry of National Policies \& Economic Affairs, Department of Census and Statistics. Colombo: Ministry of National Policies \& Economic Affairs.

- Dessler, G., \& Varkkey, B. (2009). HUMAN RESOURCE 
MANAGEMENT (11 ed.). New Delhi, India: Dorling Kindersley (India) Pvt. Ltd.

- Dumay, J., \& Rooney, J. (2011). Dealing with an ageing workforce: current and future implications. Journal of Human Resource Costing \& Accounting, 15(3), 174-195. Retrieved July 07, 2017

- Emanuel, D., Simon, F., \& Segars, B. M. (2016). Aging and motivation to stay employable. Journal of Managerial Psychology, 31(3), 1-25. Retrieved March 01, 2016

- Fasbender, U., Wang, M., Voltmer, J.-B., \& Deller, J. (2015, June 3). The Meaning of Work for Post retirement Employment Decision. Work, Aging and Retirement, 2, 1223.

- Fawaz, Y. (2017, April). To claim or to retire: the social security claiming decision of employed and unemployed workers. International Journal of Manpower, 38(3), 2-27. doi:10.1108/IJM-08-2015-0127

- Feldman, D. C., \& Turnley, W. H. (1995). Factors Influencing Intentions to Retire: An Empirical Test of Theoretical Propositions. Management Research News, 18, 2845.

- Flynn, M. (2010). Who would delay retirement? Typologies of older workers. Personnel review, 39(3), 308-324. Retrieved July 07, 2017

- Gamage, P. (2013). Industrial Law. Colombo, Sri Lanka: S. Godage and Sons (Pvt.) Ltd.

- $\quad$ Hallberg, D., \& Eklof, M. (2010). Do buy-outs of older workers matter? Estimating retirement behavior with special early retirement offers.
International Journal of Manpower, 3(3), 337-359.

- Hurd, M. D. (1993). The Effect of Labour Market Rigidities on the Labour Force Behavior of Older Workers. State University of New York at Stone Brook, Department of Economics. New York: National Bureau of Economic Research.

- Kautonen, T., Hytti, U., Bogenhold, D., \& Heinonen, J. (2012). Job satisfaction and retirement age intentions in Finland. International Journal of Manpower, 33(4), 424440.

- Kodama, T. (2015). Elderly Employment in Japan. Daiwa Institute of Research, Economic Research Department, Tokyo.

- Kooij, D., Lange, A. d., Jansen, P., \& Dikkers, J. (2008). Older workers' motivation to continue to work: five meanings of age: A conceptual review. Journal of Managerial Psychology, 23(4), 364-394. Retrieved April 28, 2015

- Kuhn, J. M. (2013). Age, Retirement and Establishment Closure. International Journal of Manpower, 536-551.

- Kwasniewski, B. W. (2010). The End of Mandatory Retirement: Legal Implications for Employers.

- Lain, D., \& Loretto, W. (2016). Managing employees beyond age 65 : from the margins to the mainstream? Employee Relations, 38(5), 646-664. Retrieved July 06, 2017

- Lim, V. K. (2003). An empirical study of older workers' attitudes towards the retirement experience. Employee Relations, 25(4), 330-346. Retrieved July 07, 2017 
- Messe, P.-J. (2012). Do discriminatory attitudes to older workers at work affect their retirement intentions? International Journal of Manpower, 33(4), 405423.

- Newton, B. (2006). Training an agediverse workforce. industrial and Commercial Training, 38(2), 93-97. Retrieved July 07, 2017

- Parliament, H. o. (2011, October). Retrieved from www.parliament.uk/post: http://www.parliament.uk/post

- $\quad$ Patrickson, M., \& Ranzijn, R. (2003). Employability of older workers. Equal Opportunities International, 22(5), 50-63.

- Paul, R., Kate, W., \& Black, E. (2015). It's never too late to learn. Journal of Workplace Learning, 27(6), 457-472.

- $\quad$ Roper, K. O., \& Yeh, D. C. (2007). Ergonomic solutions for an aging workforce. Journal of Facilities Management, 5(3), 172-178.

- $\quad$ Saunders, M., Lewis, P., \& Thornhill, A. (2009). Research Methods for Business Students (5th ed.). Harlow, Essex, England: Pearson Education Limited.

- Schlosser, F., Zinni, D., \& Armstrong-Stassen, M. (2012). Intention to Unretire: HR and the boomerang effect. Career Development International, 17(2), 149-167. Retrieved July 07, 2017

- Sekaran, U. (2010). Research Methods for Business - A Skill Building Approach. (J. Marshall, Ed.) New York, NY, USA: John Wiley \& Sons, Inc.
- $\quad$ Shacklock, K., \& Brunetto, Y. (2011). A model of older workers' intentions to continue working. Personnel Review, 40(2), 252-274. Retrieved June 19, 2016

- $\quad$ Shultz, S. K., \& Henkens, K. (2010). Introduction to the Changing Nature of Retirement: An International Perspective. International Journal of Manpower, 265-270.

- Stamov, C., \& Biemann, T. (2012). Ageing and work motivation: a task level perspective. Journal of Managerial Psychology, 27(5), 459478. Retrieved July 07, 2017

- $\quad$ Templer,, A., Armstrong-Stassen, M., \& Cattaneo,, J. (2010). Antecedents of older workers' motives for continuing to work. Career Development International, 15(5), 479-500. Retrieved October 26, 2017.

- $\quad$ Topa, G., \& Alcover, C.-M. (2015). Psychological factors in retirement intentions and adjustment: a multisample study. Career Development Journal, 20(4), 384-408. Retrieved July 06, 2017

- $\quad$ Tucker, L. R., \& MacCallum, R. C. (1997). Exploratory Factor Analysis. Ohio: Ohio State University Press.

- $\quad$ Turek, K., \& Perek-Bialas, J. (2013). The role of employers opinions about skills and productivity of older workers: example of Poland. Employee Relations, 35(6), 648-664.

- Vodopivec, M., \& Arunatilake, N. (2008, April). The Impact of Population Aging on the Labor Market: The Case of Sri Lanka.

- Walker, J. (1990). Is There a Future for Retirement Education? Employee Counselling Today, 2(4), 21 - 27. 
Perera E.A.Y.D., Weerakkody W.A.S., KJM, 2018, 7 (2)

- Wilson, D. B., \& Parry, E. (2013). Career Progression in Older Managers. Employee Relations, 35(03), 309-321. doi:10.1108/01425451311320495

- World Health Organization. (2015). World Report on Ageing and Health. United Nations. Luxembourg: WHO.

- Zacher,, H., \& Rudolph, C. W. (2017). Successful Aging at Work and Beyond: A Review and Critical Perspective. Australia: Emerald Group of Publishing. 